Arq. Bras. Med. Vet. Zootec., v.70, n.3, p.758-766, 2018

\title{
Parotid gland adenocarcinoma in a cow: case report
}

[Adenocarcinoma de glândula parótida em vaca: relato de caso]

P.J.B. Queiroz, T.D. Queiroz, P.L. Magalhães, N.C. Borges, D.B. Martins, V.M.B.D. Moura, L.A.F. Silva

Universidade Federal de Goiás (UFG) - Escola de Veterinária e Zootecnia (EVZ) - Goiânia, GO

\begin{abstract}
A 9-year-old Girolando dairy cow, weighing 400kg, with a history of increased volume in the right parotid region, which extended to the submandibular region, was assisted. Fine needle aspiration cytology was performed, and the cytological findings were consistent with malignant neoplasm of epithelial origin (carcinoma). Because of the unfavorable prognosis, the animal was euthanized and submitted to an anatomopathological examination. Samples of the increased parotid and affected lymph nodes were collected for histopathological evaluation. The microscopic changes were accentuated features of anaplasia, moderate cell proliferation, atypical mitotic figures, and necrosis. Stroma ranged from delicate to scirrhous, and the tumor boundaries were not distinct. These findings substantiated the preliminary histomorphological diagnosis of undifferentiated carcinoma with metastasis in lymph nodes. Immunohistochemical tests were performed with anti-CK Pan (clone AE1AE3), anti-CK HMW (clone 34ßE12), anti-CK19 (clone RCK108), anti-vimentin (clone V9), anti-S100 (polyclonal), and antiandrogen (polyclonal) antibodies. The immunophenotype favored the diagnosis of salivary gland adenocarcinoma. Despite the rareness in cattle, salivary gland adenocarcinoma should be considered in the differential diagnosis of diseases that occur with increased volume in the head, lymphadenopathy, drooling, dysphagia, and progressive weight loss.
\end{abstract}

Keywords: cattle, cytology, immunohistochemistry, malignant neoplasms, salivary glands

\section{RESUMO}

Foi atendida uma vaca da raça Girolando, de nove anos de idade, de aptidão leiteira, pesando aproximadamente $400 \mathrm{~kg}$ e com histórico de aumento de volume na região parotídea e submandibular direita. Diante do prognóstico desfavorável, o animal foi submetido à eutanásia e encaminhado para exame anatomopatológico. Fragmentos da glândula parótida e dos linfonodos alterados foram colhidos e encaminhados para exame histopatológico. À avaliação microscópica, observaram-se acentuada anaplasia, moderada proliferação celular, figuras de mitose atípicas e focos de necrose. O estroma variava de delicado a esquirroso e os limites do tumor eram imprecisos. Esses achados fundamentaram o diagnóstico de carcinoma indiferenciado com metástase em linfonodos. No exame imuno-histoquímico, foram utilizados anticorpos primários monoclonais anti-CK Pan (clone AE1AE3), anti-CK alto peso molecular (clone 34ßE12), anti-CK19 (clone RCK108), antivimentina (clone V9), anti-S100 (policlonal) $e$ antirreceptor de andrógenos (policlonal). As células neoplásicas apresentaram imunomarcação para todos os anticorpos testados, resultado que favorece o diagnóstico de adenocarcinoma de glândula salivar. Embora raro em bovinos, o adenocarcinoma de glândula salivar deve ser considerado no diagnóstico diferencial de doenças que cursam com aumento de volume na cabeça, linfadenopatia salivação, disfagia e emagrecimento progressivo.

Palavras-chave: bovino, citologia, glândulas salivares, imuno-histoquímica, neoplasia maligna

Recebido em 15 de novembro de 2016

Aceito em 22 de novembro de 2017

E-mail: paulojose.vet@hotmail.com 


\section{INTRODUCTION}

Salivary gland tumors (SGTs) are a heterogeneous group of neoplasms that present complex morphological appearance, sometimes making the diagnosis difficult (Jones et al., 2008). They are a rare occurrence in animals, but cases have been described in several species (Uzal et al., 2016). Nevertheless, they are considered a highly rare cancer in bovines (Lucena et al., 2011).

SGTs most often occurs in older animals, justifying the low occurrence in farm animals, which are usually slaughtered at a young age (Head et al., 2002). The main clinical signs are swelling of the affected gland, pain, halitosis, dysphagia, and exophthalmia. The occurrence of metastasis in regional lymph nodes or other organs is common, especially in the lung (Uzal et al., 2016).

The aim of this study was to report the clinical, laboratory, cytological, pathological, and immunohistochemical findings in a case of adenocarcinoma of the parotid gland in a cow.

\section{CASE REPORT}

A 9-year-old Girolando dairy cow weighing $400 \mathrm{~kg}$ with a history of increased volume in the right parotid region, which extended to the submandibular region (Figure 2A) was assisted.
According to the owner, the swelling began approximately two years before and occurred gradually, causing difficulty in swallowing, drooling, and weight loss. On clinical examination, the distended volume had a firm consistency, was motionless and painless. There was also an increase in the volume of the right lateral submandibular and retropharyngeal lymph nodes. The other clinical parameters were within normal limits.

Blood samples were collected for complete blood count (CBC) and measurement of total serum protein (TSP) and fibrinogen. The tests revealed leukocytosis $\left(14.000 \mathrm{~mm}^{3}\right.$, of $\left.4.000-12.000 \mathrm{~mm}^{3}\right)$, lymphocytosis $\left(9.100 \mathrm{~mm}^{3}\right.$, of $\left.2.500-7.500 \mathrm{~mm}^{3}\right)$, discrete hyperproteinemia $(7.6 \mathrm{~g} / \mathrm{dL}$, of 6.35 $7.53 \mathrm{~g} / \mathrm{dL})$ and hyperglobulinaemia $(4.58 \mathrm{~g} / \mathrm{dL}$, of $3-3.97 \mathrm{~g} / \mathrm{dL})$.

Fine needle aspiration cytology (FNAC) was performed, and the cytological samples presented an epithelial-like morphology with cytoplasmic basophilia and vacuolation. The nuclear changes were karyomegaly, multinucleation, nuclear molding, coarse chromatin, single or multiple prominent nucleoli, and anisonucleosis. There were also aberrant mitotic figures, anisocytosis, discreet pleomorphism, signet ring cell, and cellular cannibalism (Figure 1). The findings were consistent with malignant neoplasm of epithelial origin (carcinoma).
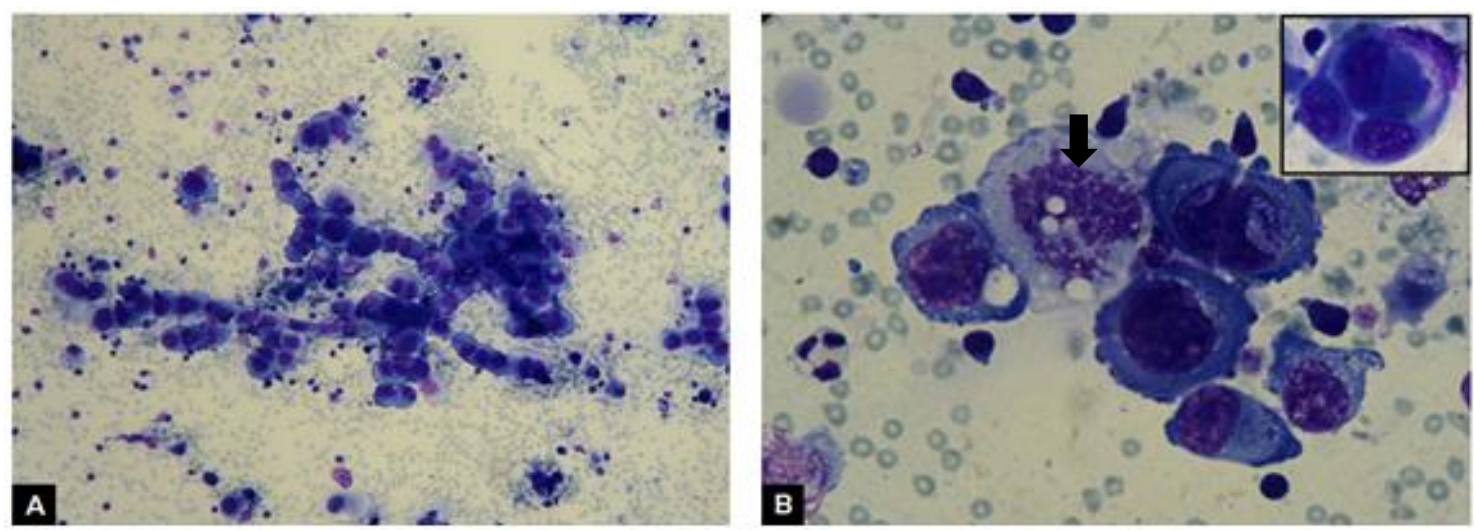

Figure 1. A. hypercellular sample showing epithelial cells arranged in clusters and cords. Diff-Quick; magnification x20. B. Neoplastic epithelial cells showing malignant characteristics such as anisocytosis, cellular molding, basophilia, and slight vacuolation. Nuclear changes include anisokaryosis, rounded to irregular nucleoli, loose and coarse chromatin, and single or multiple prominent nucleoli. Aberrant mitosis (arrow) and cannibalism (in detail) are also present. Diff-Quick; magnification x100. 
Because of the unfavorable prognosis, the animal was euthanized and submitted to an anatomopathological examination. In the macroscopic evaluation, a solid increase of volume in the right parotid region was observed, extending anteriorly to the masseteric fossa and adhered to the posterior portion of the right mandibular arch. The increase was delimited,

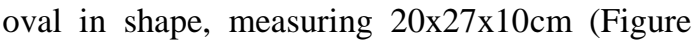

2B), yellowish, with firm consistency and heterogeneous cut surface (Figure 2C). The right lateral submandibular and retropharyngeal lymph nodes were increased as well as those from the mediastinal and tracheobronchial chain. At the cutting surface, these structures had the same characteristics as the increase in the parotid region (Figure 2D). Other findings included pleural adhesions and splenic abscess.
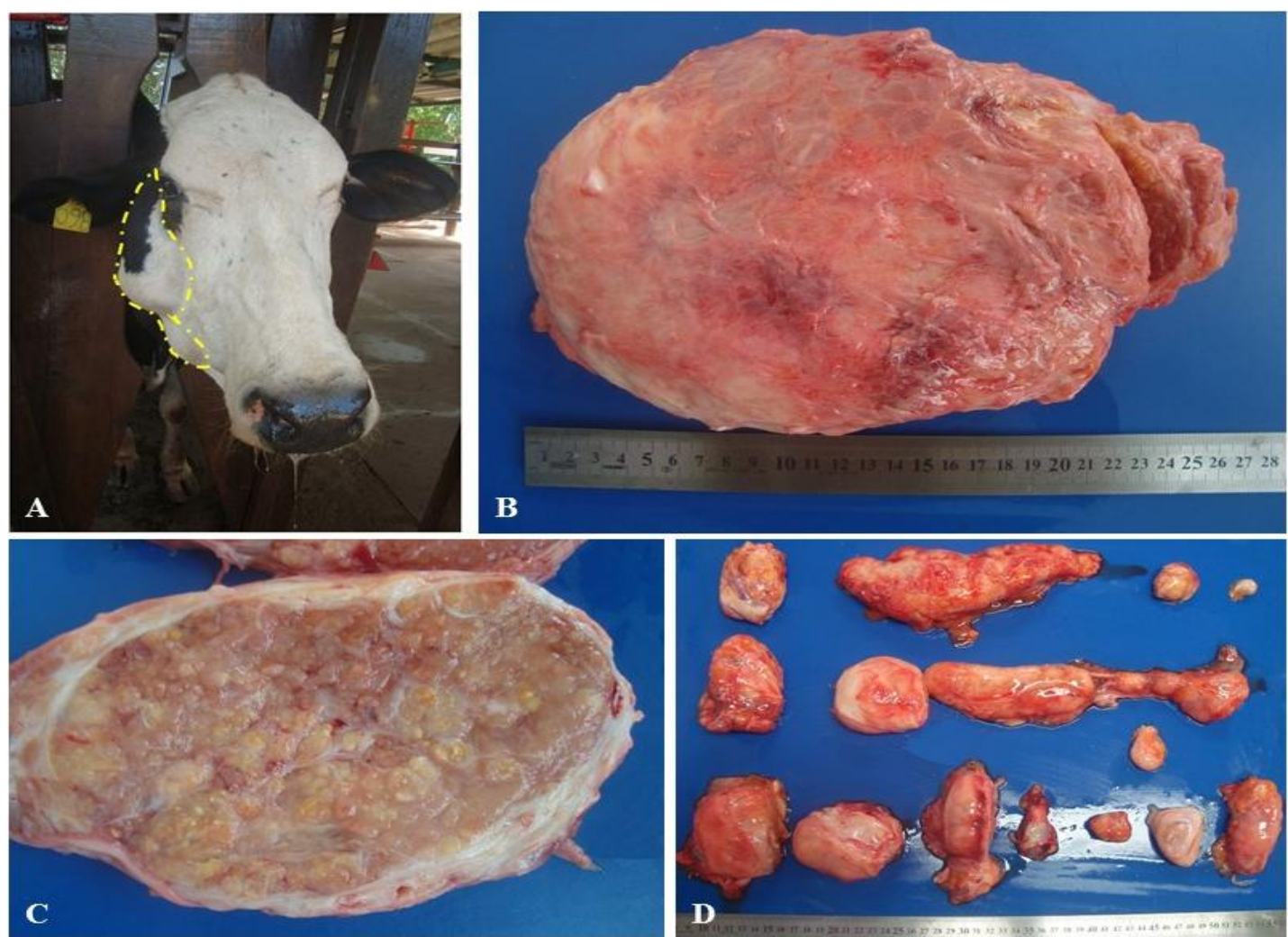

Figure 2. A. Cattle, Girolando dairy cow, presenting ptyalism and swelling in the right parotid region, extending to the submandibular region (dotted line). B. Gross appearance of the tumor. C. Cutting surface of the neoplasia. Lobed appearance, brownish and yellowish areas. D. Increase of the right lateral submandibular and retropharyngeal lymph nodes, and of the mediastinal and tracheobronchial lymphatic chain.

Samples of the parotid increase and of the affected lymph nodes were collected for the histopathological examination. Proliferation of neoplastic epithelial cells arranged in blocks, sometimes forming lobes, was observed in the microscopic evaluation of parotid and lymphatic tissues. The cells had a round morphology, abundant eosinophilic cytoplasm, large and round nucleus, with single or multiple prominent nucleoli. The tumor showed intense features of anaplasia, middle cell proliferation (2-3 mitotic figures per high power field), atypical mitotic figures, neoplastic cell emboli in vessels, foci of necrosis, stroma ranged from delicate to scirrhous, and the tumor boundaries were not distinct. There were also severe and multifocal interstitial mononuclear inflammatory infiltrate. These findings supported the preliminary histomorphological diagnosis of undifferentiated carcinoma with metastasis in lymph nodes. Adenocarcinoma of salivary glands and squamous cell carcinoma, both undifferentiated, were considered as differential diagnosis. 
To determine the immunophenotype and confirm the neoplastic origin, immunohistochemical panel was performed with the following antibodies: anti-CK Pan (clone AE1AE3, Invitrogen, \#MA5-13156, 1:200), anti-CK HMW (clone 34ßE12, Dako, \#M0630, 1:50), anti-CK19 (clone RCK108, Dako, \#M0888, 1:100), antivimentin (clone V9, Invitrogen, \#MA5-11883, 1:200), anti-S100 (polyclonal, Dako, \# Z0311, 1:1000), and anti-AR-N20 (polyclonal, Santa Cruz, \#SC816, 1:50). The immunohistochemical tests for all antibodies were performed using the same protocol, which included endogenous peroxidase blocking (Peroxide Block, Cell Marque, \#925B), antigenic retrieval ( $\mathrm{pH}$ 6,0 citrate buffer, Dako Cytomation Pascal Pressure Cooker), protein blocking (Protein Block SerumFree, Dako, \#X0909), incubation with each primary antibody (overnight at $4^{\circ} \mathrm{C}$ ), incubation with a polymer/secondary antibody kit
(Histofine Simple Stain TM MAX PO MULTI, mouse/rabbit, \#414152F), and chromogen/substrate kit for signal detection (Dako Liquid DAB-Substrate Chromogen System, \#K3468). The sections were counterstained with Harris hematoxylin, washed, dehydrated, coverslipped, and examined by light microscopy. A sample from normal bovine skin (CK Pan, CK HMW, CK19, and vimentin) and canine melanoma (S100 and AR-N20) were used as positive control. For negative control, PBS buffer was used to replace primary antibodies.

Despite the varying distribution, the neoplastic cells were positive for all tested antibodies. In this case the immunophenotype favored the diagnosis of salivary gland adenocarcinoma. Figure 3 shows the histopathological and immunohistochemical findings of the neoplasia.
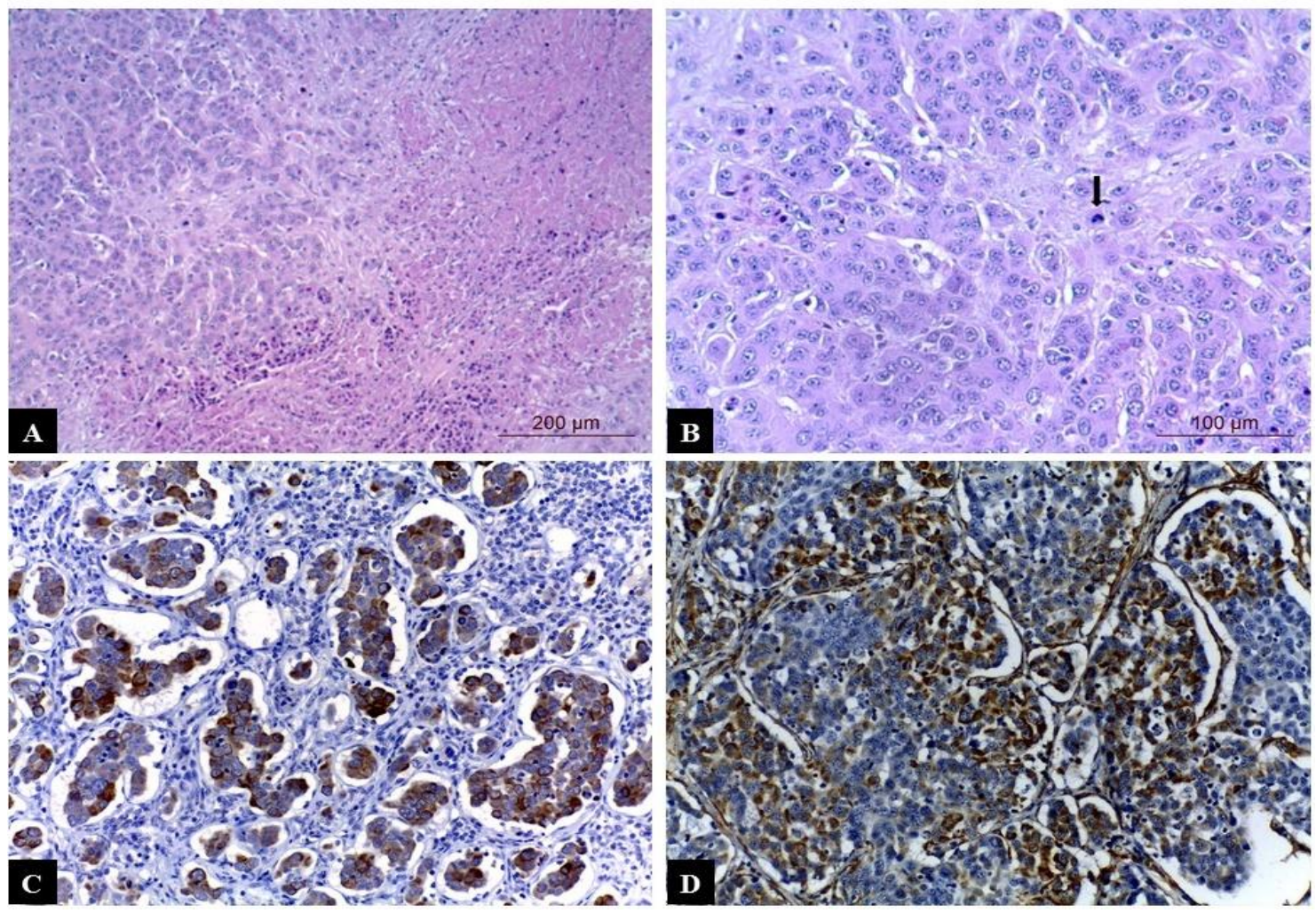

Figure 3. Adenocarcinoma of the salivary gland in a bovine. A. In the left, proliferation of neoplastic epithelial cells. Cells grouped in blocks. In the right, extensive necrotic area. HE; magnification x100. B. Neoplastic epithelial cells with eosinophilic cytoplasm, large nucleus, round to oval, with one or more evident nucleoli and atypical mitotic figure (arrow). HE; magnification x200. C. Positive immunostaining for anti-CK19 in neoplastic cells. IHQ; magnification x100. D. Positive immunohistochemical staining for anti-vimentin in neoplastic epithelial cells and in the stromal cells. IHQ; magnification x200 


\section{DISCUSSION}

SGTs are rare in all species, although this type of cancer has been described with greater frequency in dogs and cats (Uzal et al., 2016). In a retrospective study the records of 6,706 necropsy examinations in cattle over a period of 45 years were evaluated, with the identification of 586 cases of cancer, none of which involving salivary glands (Lucena et al., 2011). The SGTs affects mainly older animals (Head et al., 2002; Uzal et al., 2016). Thus, the low occurrence of SGTs in cattle is mainly related to the slaughter of young animals, especially cattle for meat production. Dairy cows remain longer in the production system and, therefore, are more prone to develop SGTs.

The cattle of this report showed a progressive increase in volume in the right parotid region, difficulty in swallowing, drooling and weight loss. The progression of clinical signs occurred slowly since the owner claimed to observe the changes in the first two years. The most common clinical signs of SGTs are a gradual increase in volume and/or the presence of a painless mass in the region of the salivary gland (Mazzullo et al., 2005). Other clinical signs commonly result from the compression exerted by the tumor on adjacent anatomical structures and include halitosis, anorexia, dysphagia, sneezing, weight loss, exophthalmia, epiphora, strabismus, and Horner's syndrome (Bercier et al., 2013).

Confirming the chronic history of this case, the results of the laboratory tests showed chronic inflammation. In cattle, the observation of a chronic leukogram is complicated due to the animals typical response to this type of inflammation, and just in some cases, a slight increase in the populations of neutrophils, lymphocytes, and monocytes is observed (Jones and Allison, 2007). These amendments are accompanied by changes in the values of serum protein concentrations, which is one of the main laboratory abnormalities found in most diseases (Thrall, 2007). In ruminants, the most common causes of lymphocytosis and hyperproteinemia by hyperglobulinaemia are the chronic aspect of infections, especially in pneumonia, peritonitis, pericarditis, and abdominal abscesses (Smith, 2015). Although macroscopic changes that justify the frame were found in the anatomopathological examination, such as splenic abscess, the progressive alterations in the parotid gland are the most probable cause for the hematological findings.

In this report, due to the size of the lesion and its disposal, an ultrasound was used to guide the needle when the material was harvested for cytological examination, which allowed the evaluation of the site to be punctured, ensuring the quality of the sample. FNAC is a useful test to diagnose changes in salivary glands, being a fast technique and easy to apply. If necessary, the procedure can be repeated to obtain new and better samples (Sauer et al., 1992). Although FNAC does not often allow diagnosis with wellestablished classification, such as histopathology offers, it can confirm the origin of the injury (Whitney and Berent, 2010). In this case specifically, it had a neoplastic origin and involved epithelial cells, which was ratified in the histopathology and immunohistochemistry.

SGTs, when differentiated, tend to exhibit typical morphology of their origin cell type (Chaudhry et al., 1986), reproducing cell patterns considered to be normal for the tissue (Head et al., 2002). The cells observed in the cytology had the morphology of epithelial origin, demonstrating cuboids to round shapes, size ranging from small to large, well-defined cellular limits when individualized or grouped. However, such identification is difficult as the malignant tumor become anaplastic (Head et al., 2002). Moreover, salivary gland tumors in cattle have been described only by histopathology (Bundza, 1983; Salgado et al., 2012), descriptions of such neoplasias by FNAC are rare. The absence of cytologic descriptions complicates the diagnosis of these tumors, especially when they have a high degree of malignancy. On the other hand, it is possible to determine some findings by observing and comparing with other neoplasms of glandular origin, as well as comparing with descriptions of cytological salivary gland tumors in humans.

In cytological samples, malignant characteristics are based on the observation of the cell population morphology, being atypia and/or anaplasia a common finding. These characteristics are divided into general and nuclear, with the first one being less unspecific since they are also present in non-neoplastic diseases, such as inflammation and hyperplasia 
(Meinkoth et al., 2009). In the bovine samples of this case, some of the nuclear characteristics observed were multinucleation, angulated nucleoli and anisonucleosis, with anisocytosis being the main general characteristic. This information, together with the epithelial characteristics, indicated the tumor in question is a carcinoma, and its salivary gland origin was confirmed by histopathologic and immunohistochemical examinations.

The cell cannibalism observed in this cytological exam refers to the phagocytic activity of neoplastic cells engulfing a cell of the same origin (Klionsky, 2004), which is classified as homotypic (Sharma and Dey, 2011). This finding has been studied extensively in human pathology (Fais, 2007; Singhal et al., 2011), it is not unique to tumor cells and can also be performed by nonphagocytic cells (Klionsky, 2004). Cannibalism is observed mainly in carcinomas and, in humans, it is associated with metastasis and poor prognosis (Fais, 2007; Singhal et al., 2011). However, in domestic animals, there are still few reports and studies on this phenomenon in cytological tumors samples (Melendez-Lazo et al., 2015).

The cytological material also had cells with large cytoplasmic vacuoles that dislocated the nucleus to the periphery. These cells are known as signet ring cells, considered malignant and, when present, they suggest an accumulation of secretory content (Raskin and Meyer, 2010). They can be observed in clusters or individual cells, indicating loss of cell cohesion. These cells are occasionally found in adenocarcinomas that accumulate mucin (Sung et al., 2008), being also reported in salivary gland adenocarcinomas (Bastaki and Summersgill, 2010), gastric neoplasia (Taniuchi et al., 2015), and ovarian cancer (Raskin and Meyer, 2010).

The anatomopathological examination confirmed the diagnosis of right salivary parotid gland adenocarcinoma with metastases in regional, mediastinal, and tracheobronchial lymph nodes. In animals, a higher incidence of cancer is observed in the parotid and mandibular salivary glands. Metastases in regional lymph nodes and lungs have been described as common (Uzal et al., 2016); however, in this case, pulmonary infiltration was observed. Microscopically, the neoplasm of the present description showed epithelial cells arranged in clusters, sometimes forming lobes, suggesting a structural glandular pattern (Lewis et al., 2016). The cell morphology was variable, but predominantly rounded, with abundant eosinophilic cytoplasm. The nucleus was large, round, with single or multiple prominent nucleoli, displaying anisokaryosis and macrokaryosis. There was also marked anaplasia, limiting the histomorphological diagnosis in undifferentiated carcinoma since the neoplastic histomorphology often showed a pattern of squamous epithelial differentiation. Therefore, it was considered as a differential diagnosis of salivary glands adenocarcinoma and squamous cell carcinoma, both undifferentiated. Although adenocarcinoma of salivary gland in cattle is rare, there are reports of similar microscopic description (Salgado et al., 2012).

The immunohistochemical technique was used as a complementary diagnostic tool because it allows to determine the immunophenotype of undifferentiated tumors, helping confirm neoplastic cell origin (Ramos-Vara et al., 2008). Anti-cytokeratin monoclonal antibodies have been used to identify epithelial neoplasms of the salivary glands of animals with varying degrees of success (Head et al., 2002). In this case, the neoplastic cells exhibited positive immunostaining for anti-CK Pan antibody (AE1AE3), anti-CK HMW (34ßE12 clone), and anti-CK19 (RCK108 clone), characterizing the epithelial origin of the neoplasm. In addition, the positivity for anti-CK19 antibody support the hypothesis that these cancer cells have their origin in a simple epithelium of glandular type since the low molecular weight cytokeratin compose the structure of these cell types (Moll et al., 1982; Pastuszak et al., 2015).

Furthermore, the positive immunohistochemical staining for anti-vimentin antibody and anti-S100 suggests the neoplasm of this description has its origin in the myoepithelial cells of the salivary gland epithelium because this cell type commonly presents immunostaining for these antibodies (Zhu et al., 2015). Vimentin is a protein normally present in mesenchymal cells, but it can be detected in poorly differentiated carcinomas (Bhargava and Dabbs, 2014). In this report, it is possibly due to the biological processes known as dedifferentiation and epithelial-mesenchymal transition, which may occur in neoplastic cells of malignant biological 
behavior (Korita et al., 2010). In contrast, in another case of salivary adenocarcinoma in cattle, neoplastic cells showed no immunostaining for vimentin and S100, with the diagnosis of non-secretory carcinoma of salivary gland (Salgado et al., 2012).

Positive immunostaining for the androgen receptor in tumor cells of salivary adenocarcinoma was also found in this report. Regarding this, although the immunophenotypic profile of these neoplasms in bovine is unknown, in humans, it is common to find positivity for anti-RA in salivary gland adenocarcinomas that have aggressive behavior (Nasser et al., 2003), which was also observed in this case.

Initially, actinobacilosis and osteosarcoma were considered among the differential diagnoses. Caused by Actinobacillus lignieresii, actinobacillosis, despite being atypical in places other than the tongue and oral mucosa, would be a finding consistent with the region of salivary gland, justifying the presence of epithelioid cells in the harvested material. This gram-negative bacterium is part of the bovine oral and ruminal microbiota (Smith, 2015) and a case of actinobacillosis in the salivary gland has been described in a heifer of Iranian Holstein breed (Bazargani et al., 2010). However, no infectious agent was found during cytological and histopathological examinations. Besides, the osteosarcoma, despite already described as causing increased volume in the mandibular (Peixoto et al., 2016) and maxillary regions of cattle (Prins et al., 2012), was discarded by the cytological analysis. In FNAC, what is expected for this type of neoplasm, is the presence of mesenchymal cell populations with malignancy characteristics and in some cases even osteoid islands surrounded by tumor cells (Fielder and Mahaffey, 2009).

Actinomycosis, caused by the gram-positive bacterium Actinomyces bovis (Craig et al., 2016), was not considered as a differential diagnosis because no multiple piogranulomas were found among bone trabeculae, lesions typical of this condition (Tessele et al., 2014). The bovine epizootic periodontitis, a purulent periodontitis capable of causing chronic ossifying periostitis, was also discarded, since the animal had already passed the phases of tooth eruption and there were no oral lesions on the marginal gingiva or periodontal pockets (Döbereiner et al., 2004).

In veterinary, the information about the classification standards and behavior of tumors of salivary glands in different domestic species are restricted and, when presented, most available data refers to canine and feline species, possibly because of infrequent occurrence and the few reported cases. However, considering the histological classification proposed by the World Health Organization for salivary gland tumors in animals (Head et al., 2003) and the immunophenotypic profile presented, the bovine neoplasia in this report fits the diagnosis of salivary gland adenocarcinoma. The importance of such reports must be emphasized regarding the need for knowledge in order to classify and identify the behavior of these tumors in cattle.

\section{CONCLUSION}

Although rare in cattle, salivary gland adenocarcinoma should be considered in the differential diagnosis of diseases that occur with increased volume in the head, lymphadenopathy, drooling, dysphagia, and progressive weight loss. The cytological, histological and immunohistochemical characterizations of this type of tumor in cattle are central to confirm the diagnosis.

\section{ACKNOWLEDGMENTS}

We thank Dr. Rafael Torres Neto for the excellent technical assistance in immunohistochemical test.

\section{REFERENCES}

BASTAKI, J.; SUMMERSGILL, K. Signet-ring cell (mucin-producing) adenocarcinoma of minor salivary glands: report of a case. Oral Surg. Oral Med. Oral Pathol. Oral Radiol. Endod., v.110, p.e33-36, 2010.

BAZARGANI, T.T.; TAFTI, A.K.; ATYABI, N.; FAGHANIZADEH, G.H. An unusual occurrence of actinobacillosis in heifers and cows in a dairy herd in Tehran suburb-Iran. Arch. Razi Inst., v.65, p.105-110, 2010.

BERCIER, M.; GUZMAN, D.S.M.; STOCKMAN, J. et al. Salivary gland adenocarcinoma in a domestic rabbit (Oryctolagus cuniculus). J. Exot. Pet Med., v.22, p.218-224, 2013. 
BHARGAVA, R.; DABBS, D.J. Immunohistology of metastatic carcinoma of unknown primary site. In: DABBS, D.J. (Ed.). Diagnostic immunohistochemistry: theranostic and genomic applications. 4.ed. Philadelphia: Elsevier, 2014. p.204244.

BUNDZA, A. Primary salivary gland neoplasia in three cows. J. Comp. Pathol., v.93, p.629-632, 1983.

CHAUDHRY, A.P.; CUTLER, L.S.; LEIFER, C. et al. Histogenesis of acinic cell carcinoma of the major and minor salivary glands. An ultrastructural study. $J$. Pathol., v.148, p.307-320, 1986.

CRAIG, L.E.; DITTMER, K.E.; THOMPSON, K.G. Inflammatory and infectious diseases of bones. In: MAXIE, M.G. (Ed.). Jubb, Kennedy \& Palmer's pathology of domestic animals. 6.ed. Missouri: Elsevier, 2016. v.1, p.97-107.

DÖBEREINER, J.; DUTRA, I.S.; ROSA, I.V. A etiologia da "cara inchada", uma periodontite epizoótica dos bovinos. Pesqui. Vet. Bras., v.24, p.5056,2004

FAIS, S. Cannibalism: a way to feed on metastatic tumors. Cancer Lett., v.258, p.155-164, 2007.

FIELDER, S.E.; MAHAFFEY, E.A. Sistema musculoesquelético. In: COWELL, R.L.; TYLER, R.D.; MEINKOTH, J.H.; DENICOLA, D.B. (Eds.). Diagnóstico citológico e hematologia de cães e gatos. 3.ed. São Paulo: Medvet, 2009. p.20-46.

HEAD, K.; ELSE, R.; DUBIELZIG, R. Tumors of the alimentary tract. In: MEUTEN, D.J. (Ed.). Tumors in domestic animals. 4.ed. Ames: Iowa State Press, 2002. p.410-416.

HEAD, K.W.; CULLEN, J.M.; DUBIELZIG, R.R. et al. Histological classification of tumors of the alimentary system of domestic animals. 2.ed. Washington: Armed forces Institute of Pathology in Cooperation with the American Registry of Pathology and the World Health Organization Collaborating Center for Worldwide Reference on Comparative Oncology, 2003. 257p.

JONES, A.V.; CRAIG, G.T.; SPEIGHT, P.M.; FRANKLIN, C.D. The range and demographics of salivary gland tumours diagnosed in a UK population. Oral Oncol., v.44, p.407-417, 2008.

JONES, M.L.; ALLISON, R.W. Evaluation of the ruminant complete blood cell count. Vet. Clin. N. Am. Food Anim. Pract., v.23, p.377-402, 2007.

KLIONSKY, D.J. Cell biology: regulated selfcannibalism. Nature, v.431, p.31-32, 2004.
KORITA, P.V.; WAKAI, T.; AJIOKA, Y. et al. Aberrant expression of vimentin correlates with dedifferentiation and poor prognosis in patients with intrahepatic cholangiocarcinoma. Anticancer Res., v.30, p.2279-2285, 2010.

LEWIS, A.G.; TONG, T.; MAGHAMI, E. Diagnosis and management of malignant salivary gland tumors of the parotid gland. Otolaryngol. Clin. N. Am., v.49, p.343-380, 2016.

LUCENA, R.B.; RISSI, D.R.; KOMMERS, G.D. et al. A retrospective study of 586 tumours in Brazilian cattle. J. Comp. Pathol., v.145, p.20-24, 2011.

MAZZULLO, G. SFACTERIA, A.; IANELLI, N. et al. Carcinoma of the submandibular salivary glands with multiple metastases in a cat. Vet. Clin. Pathol., v.34, p.61-64, 2005.

MEINKOTH, J.H.; COWELL, R.L.; TYLER, R.D. Tipos celulares e critérios de malignidade. In: COWELL, R.L.; TYLER, R.D.; MEINKOTH, J.H.; DENICOLA, D.B. (Eds.). Diagnóstico citológico e hematologia de cães e gatos. 3.ed. São Paulo: Medvet, 2009. p.211-212.

MELENDEZ-LAZO, A.; CAZZINI, P.; CAMUS, M. et al. Cell cannibalism by malignant neoplastic cells: three cases in dogs and a literature review. Vet. Clin. Pathol., v.44, p.287-294, 2015.

MOLL, R.; FRANKE, W.W.; SCHILER, D.L. et al. The catalog of human cytokeratins: patterns of expression in normal epithelia, tumors and cultured cells. Cell, v.31, p.11-24, 1982.

NASSER, S.M.; FAQUIN, W.C.; DAYAL, Y. Expression of androgen, estrogen, and progesterone receptors in salivary gland tumors. Frequent expression of androgen receptor in a subset of malignant salivary gland tumors. Am. J. Clin. Pathol., v.119, p.801-816, 2003.

PASTUSZAK, M.; GROSZEWSKI, K.; PASTUSZAK, M. et al. Cytokeratins in gastroenterology. Systematic review. Prz. Gastroenterol., v.10, p.61-70, 2015.

PEIXOTO, T.C.; SILVA, D.N.; ARAÚJO, B.R. et al. Osteossarcoma condroblástico mandibular em um bovino: relato de caso. Rev. Bras. Med. Vet., v.38, p.60-64, 2016.

PRINS, D.G.J.; WITTEK, T.; BARRETT, D.C. Maxillary osteosarcoma in a beef suckler cow: case report. Ir. Vet. J., v.65, p.1-4, 2012.

RAMOS-VARA, J.A.; KIUPEL, M.; BASZLER, T. et al. Suggested guidelines for immunohistochemical techniques in veterinary diagnostic laboratories. J. Vet. Diagn. Invest., v.20, p.393-413, 2008. 
RASKIN, R.E.; MEYER, D.J. Canine and feline cytology: a color atlas and interpretation guide. 2.ed. St. Louis: Saunders, 2010. 472p.

SALGADO, B.S.; MONTEIRO, L.N.; GRANDI, F. et al. Adenocarcinoma of the parotid salivary gland in a cow. Vet. Clin. Pathol., v.41, p.424-428, 2012.

SAUER, T.; FRENG, A.; DJUPESLAND, P. Immediate interpretation of FNA smears from the head and neck region. Diagn. Cytopathol., v.8, p.116118, 1992.

SHARMA, N.; DEY, P. Cell cannibalism and cancer. Diagn. Cytopathol., v.39, p.229-233, 2011.

SINGHAL, N.; HANDA, U.; BANSAL, C.; MOHAN H. Neutrophil phagocytosis by tumor cells-a cytological study. Diagn. Cytopathol., v.39, p.553555, 2011.

SMITH, B.P. Large animal internal medicine. 5.ed. St. Louis: Elsevier, 2015. 1712p.

SUNG, C.O.; SEO, J.W.; KIM, K.M. et al. Clinical significance of signet-ring cells in colorectal mucinous adenocarcinoma. Mod. Pathol., v.21, p.1533-1541, 2008.
TANIUCHI, K.; OOKAWAUCHI, K.; KUMON, K. et al. Intramucosal signet ring cell gastric cancer diagnosed 15 months after the initial endoscopic examination. Case Rep. Med., v.2015, p.1-5, 2015.

TESSELE, B.; VIELMO, A.; HAMMERSCHMIT, M.; BARROS C.S.L. Actinomicose atípica em bovinos. Pesqui. Vet. Bras., v.34, p.663-666, 2014.

THRALL, M.A. Hematologia e bioquímica clínica veterinária. São Paulo: Roca, 2007. 592p.

UZAL, F.A.; PLATTNER, B.L.; HOSTETTER, J.M. Salivary gland. In: MAXIE, M.G. (Ed.). Jubb, Kennedy \& Palmer's pathology of domestic animals. 6.ed. Missouri: Elsevier, 2016. v.2, p.28-30.

WHITNEY, M.S.; BERENT, L.M. The cytology of neoplasia. In: HENRY, C.J.; HIGGINBOTHAM, M.L. (Eds.). Cancer management in small animal practice. Maryland Heights: Saunders Elsevier, 2010. p.47-58.

ZHU, S.; SCHUERCH, C.; HUNT, J. Review and updates of immunohistochemistry in selected salivary gland and head and neck tumors. Arch. Pathol. Lab. Med., v.139, p.55-66, 2015. 